\title{
Article \\ Effect of Opuntia ficus-indica Mucilage Edible Coating on Quality, Nutraceutical, and Sensorial Parameters of Minimally Processed Cactus Pear Fruits
}

\author{
Giorgia Liguori $^{1, *(\mathbb{D})}$, Raimondo Gaglio ${ }^{1} \mathbb{D}$, Giuseppe Greco ${ }^{1}$, Carla Gentile ${ }^{2}\left(\mathbb{D}\right.$, Luca Settanni $^{1}$ (D) \\ and Paolo Inglese ${ }^{1}$
}

1 Department of Agricultural Food and Forest Sciences, University of Palermo, 90128 Palermo, Italy; raimondo.gaglio@unipa.it (R.G.); peppegreco199221@gmail.com (G.G.); luca.settanni@unipa.it (L.S.); paolo.inglese@unipa.it (P.I.)

2 Department of Biological, Chemical and Pharmaceutical Sciences and Technologies, University of Palermo, 90128 Palermo, Italy; carla.gentile@unipa.it

* Correspondence: giorgia.liguori@unipa.it

check for

updates

Citation: Liguori, G.; Gaglio, R.; Greco, G.; Gentile, C.; Settanni, L.; Inglese, P. Effect of Opuntia

ficus-indica Mucilage Edible Coating on Quality, Nutraceutical, and Sensorial Parameters of Minimally Processed Cactus Pear Fruits.

Agronomy 2021, 11, 1963. https:// doi.org/10.3390/agronomy11101963

Academic Editor: Valentina Scariot

Received: 6 September 2021

Accepted: 27 September 2021

Published: 29 September 2021

Publisher's Note: MDPI stays neutral with regard to jurisdictional claims in published maps and institutional affiliations.

Copyright: (C) 2021 by the authors. Licensee MDPI, Basel, Switzerland. This article is an open access article distributed under the terms and conditions of the Creative Commons Attribution (CC BY) license (https:/ / creativecommons.org/licenses/by/ $4.0 /)$.

\begin{abstract}
Cactus pear (Opuntia ficus-indica (L.) Mill.) is a non-climacteric fruit with a relatively short postharvest life span, being very sensitive to water loss, darkening and decay. Cactus pear is a spiny fruit, and the presence of glochids limits fruit consumption and diffusion; therefore, minimally processing, as well as peel removing, could be an opportunity to improve its availability, consumption, and diffusion in national and international markets. In this study, cactus pear minimally processed fruits were treated with a mucilage-based coating extracted from Opuntia ficus-indica cladodes and stored at $5{ }^{\circ} \mathrm{C}$ for 9 days. The effect of mucilage edible coating on the postharvest life, qualitative attributes, and nutraceutical value of fruit were evaluated by colors, firmness, total soluble solids content, titratable acidity, ascorbic acid, betalains and DPPH (2,2-diphenyl-1-picrylhydrazyl). Results showed that mucilage-based coating improved the quality and preserves the nutraceutical value of minimally processed cactus pear fruits during storage. The edible coating was effective in maintaining fruit fresh weight, total soluble solids content, fruit firmness, ascorbic acid and betalain content, sensorial traits, and visual score. Coated fruits showed a significantly lower microbiological growth than uncoated control fruits during the entire cold storage period.
\end{abstract}

Keywords: cactus pear; fresh-cut; betalains; antioxidant activity; microbiological growth

\section{Introduction}

Cactus pear (Opuntia ficus-indica (L.) Mill.) is cultivated for fruit production over 100,000 ha located in semi-arid areas in both hemispheres. Despite this large diffusion, cactus pear marketing is seasonal, and due to the poor post-harvest performances of the fruit, covers no more than two months in each ripening season of each cultivar [1].

In the last decades, there was an increasing interest in cactus pear fruits consumption, due to its nutritional and functional properties and its positive effects on human health [2,3]. Cactus pear is a spiny fruit, and the presence of glochids limits fruit consumption and diffusion in the international and local markets, especially in countries where cactus pear is not cultivated [1,4]. Therefore, minimally processing, such as peel removal of cactus pears fruits, could be an opportunity to improve its availability, consumption, and diffusion in national and international markets.

In recent years, the significant changes in human lifestyles produced an increase in the popularity of fresh-cut foods that are ready-to-eat; among them, the consumption of minimally processed fruit and vegetables has undergone a sharp increase and the interest of the industry in the production of fresh-cut cactus pears has led to a significant increase in per capita consumption, but its market volume still accounts for a small percentage of the total production [5]. Cactus pear is a non-climacteric fruit with a relatively short 
postharvest life span; being very sensitive to water loss, darkening and, decay; fresh fruits are also very sensitive to chilling injury [6].

The postharvest life of peeled cactus pear fruits is quite short, due to the processing operations that alter fruit integrity and cause the release of intracellular enzymes, which trigger a series of biological events leading to metabolic dysfunctions, microbial proliferation, tissue browning, off-flavor development, texture breakdown and nutraceutical value loss [5].

Among new postharvest management strategies of environmentally friendly fresh fruit handling, the application of edible coatings has been reported to be very effective [7]. Edible coatings can act as a semipermeable barrier against gases and water vapor; can modify fruit tissue metabolism by affecting respiration rate, decreasing moisture and firmness loss, preserving the color, transporting antimicrobial, antioxidant, and other preservatives, controlling microbial growth, and maintaining fruit quality for a longer period $[7,8]$. Several studies reported that the applications of edible coatings improve quality, extended storage, and shelf life of various fruit such as papaya [9], kiwifruit [10], and strawberries [11]. Del Nobile et al. [12] showed that cactus pear fruits immersion into either agar or fish protein strongly reduced the shelf life, most probably due to water migration from the surrounding hydrogel to the fresh-cut produce. On the contrary, alginate coating prolonged the shelf life of minimally processed cactus pear fruits to about 13 days.

A novel edible coating for fruit storage developed using the mucilage extracted from cladodes of Opuntia ficus-indica was recently investigated on kiwifruit slices [10], breba fig [13], strawberry [7,14], banana [15], and mandarin [16].

Those studies reported that $O$. ficus-indica edible coating positively affects fruit quality, reducing water transpiration and browning, maintaining fruit fresh weight, visual score values, fruit firmness, nutraceutical attributes, and controlling microbial growth, resulting in a longer storage period.

O. ficus-indica mucilage is a complex carbohydrate mixture composed of variable amounts of L-arabinose, D-galactose, L-rhamnose, and D-xylose, as well as galacturonic acid, which is a potential ingredient for the food industry, due to its nutritional and technological properties, such as viscosity [17]. Mucilage is, in fact, a hydrocolloid with a great water retention capacity. O.ficus-indica mucilage also containing amounts of polyphenols could be an interesting natural edible coating with a high nutraceutical value, useful for fruit and food preservation [7].

Despite the positive effect of Opuntia ficus-indica mucilage-based coating on postharvest life of several fruits, there is a lack of knowledge on the impact that this coating treatment may have on the overall qualitative, sensorial, and nutraceutical value of minimally processed cactus pear fruits during cold storage. Therefore, the aim of the present study was to evaluate the effect of the application of $O$. ficus-indica mucilage, as an edible coating, on pomological, physiochemical, sensorial, and nutraceutical parameters, and microbial growth of minimally processed cactus pear fruits during cold storage at $5 \pm 0.5^{\circ} \mathrm{C}$ and $90 \% \mathrm{RH}$.

\section{Materials and Methods}

\subsection{Cactus Pear Fruit Samples}

Cactus pear fruits were collected from 10-year-old Opuntia ficus-indica plants, cv. Gialla, spaced $6 \times 5 \mathrm{~m}$ apart and trained to a globe shape. The commercial orchard was located in Roccapalumba, Palermo, Italy $\left(37^{\circ} 48^{\prime} \mathrm{N}, 13^{\circ} 38^{\prime} \mathrm{E}, 350 \mathrm{~m}\right.$ a.s.l) on sandyloam Mediterranean red-soils. Plants were subjected to ordinary horticultural care, and the orchard was drip-irrigated. Cactus pear fruits were harvested in mid-October at commercial maturity, which was based on breakage peel color (green-yellow) and were quickly moved to the nearby laboratory.

After harvest, fruits were promptly sorted for homogenous size and no defects. Cactus pear selected fruits were then washed in tap water, sanitized by immersion in $200 \mathrm{mg} \mathrm{kg}^{-1}$ 
of sodium hypochlorite for $5 \mathrm{~min}$, and left to dry at room temperature. Afterwards, approximately $0.5 \mathrm{~cm}$ of fruit peel was removed from each distal end by cutting with a sharp knife, and the peel was then carefully removed along the longitudinal axis.

Only peeled fruits with no external injuries were selected, fruit processing operations were carried out in sanitary conditions at $18^{\circ} \mathrm{C}$.

\subsection{Fresh Mucilage Extraction and Application}

One-year-old cladodes were collected from four-year-old O. ficus-indica (OFI) plants of the cultivar "Gialla", located in the Department of Agricultural, Food and Forest Sciences, University of Palermo ( $38^{\circ} 7^{\prime} 4.0800^{\prime \prime} \mathrm{N} 13^{\circ} 22^{\prime} 11.2800^{\prime \prime}$ E, $29 \mathrm{~m}$ a.s.l). Three cladodes (one-year-old cladodes) were harvested from the same plant for mucilage extraction. Harvested cladodes were packaged, and transported to the laboratory where they were measured, weighed, and processed for mucilage extraction, using a modified patented method of Du Toit and De Witt developed in South Africa [18].

Cladodes were washed with chlorinated water to improve mucilage shelf life to remove impurities and spines. Cladodes chlorenchyma was removed with a peeler to obtain highly pure quality mucilage. Cladodes were then sliced into squares and cooked in a microwave oven $(900 \mathrm{~W})$ for 3-5 min, until soft. The cooked, soft cladode pieces were then blended using an Omni Mixer Homogenizer (mod. Omni-Mixer. 17107, Dupont Instruments Sorvall, Modesto, CA, USA) to aid in the mucilage extraction. The obtained pulp was then centrifuged using a Sigma centrifuge (mod. 6K15, Sigma Laborzentrifugen $\mathrm{GmbH}$, Osterode am Harz, Germany) at $8117 \times g$ for $15 \mathrm{~min}$ at $4{ }^{\circ} \mathrm{C}$, to separate the liquid mucilage from the solids. The mucilage was then decanted and weighed while the solid material left in the falcon tubes were discarded. No chemicals were used during this extraction process and as such, the extracted mucilage obtained is natural and unadulterated by chemicals. Work surface area and cutting tools were washed and sanitized with $200 \mathrm{mg} \mathrm{kg}^{-1}$ of sodium hypochlorite before and during fruit processing.

After cutting, cactus pear fruits were divided into two treatment groups (control: OFI C and coated: OFI M). Each sampling group consisting in 5 replicates ( 3 fruits each) for each of 4 sampling dates, plus 20 replicates ( 3 fruits each) for sensory analysis and visual score ( 5 replicates for each sampling date) and 5 replicates ( 3 fruits each) for weight loss monitoring.

OFI M samples were treated with OFI mucilage, and OFI C samples were treated with distilled water and used as control. Mucilage edible coating and distilled water were applied by using an atomizing spray system (flow rate: $1 \mathrm{~L} \mathrm{~h}^{-1}$; air pressure: $50 \mathrm{kPa}$ ). Soon after coating, all fruits were air-dried at room temperature for $15^{\prime}$, then, coated and uncoated samples (OFI M and OFI C), were placed in rigid polypropylene $25 \times 20 \mathrm{~cm}$ retail boxes ( 3 peeled cactus pear fruits for each box), sealed with $35 \mu \mathrm{m}$ microperforated polypropylene film $\left(\mathrm{O}_{2}\right.$ permeability: $\sim 12,000 \mathrm{~mL} \mathrm{~m}^{-2} \mathrm{~d}^{-1} \mathrm{~atm}^{-1}, \mathrm{CO}_{2}$ permeability: $\sim 13,000 \mathrm{~mL} \mathrm{~m}^{-2} \mathrm{~d}^{-1} \mathrm{~atm}^{-1}$ at $5{ }^{\circ} \mathrm{C}$ ) and stored at $5 \pm 0.5^{\circ} \mathrm{C}$ and $95 \% \mathrm{RH}$ for 9 days.

\subsection{Quality Parameters: Firmness, Soluble Solid Content, Titratable Acidity, Color, and Weight Loss}

The quality of minimally processed cactus pear fruits was assessed soon after coating $(0 \mathrm{~d})$ and at 3,6 , and 9 days of storage at $5{ }^{\circ} \mathrm{C}$. For each sampling date and experimental treatment, five samples of three cactus pear fruits were randomly chosen and analyzed.

Fruit firmness was measured using a texture analyzer (Mod. Z0.5 TS, Zwick Roell, Ulm, Germany). For penetration tests, the highest resistance $(\mathrm{N})$ opposed to the penetration of a 2-mm-diameter flat-faced cylindrical plunger to a depth of $8 \mathrm{~mm}$ and moving at a speed of $1.7 \mathrm{~mm} \mathrm{~s}^{-1}$ was recorded. Average values were calculated from the results of 5 fruits measurements ( 2 measurements for fruit) for each treatment at each sampling date.

After firmness determinations, the pulp of the fruit was cut into pieces to obtain a uniform sample of each replicate. A part was homogenized and used to measure total soluble solids (TSS) content and titratable acidity (TA), and the remaining were immediately frozen at $-80^{\circ} \mathrm{C}$ until the analysis of betalains quantification and DPPH (2,2-diphenyl- 
1-picrylhydrazyl) assay were made. Total soluble solids content (TSS) was determined by a digital refractometer (Palette PR-32, Atago Co., Ltd., Tokyo, Japan); titratable acidity (TA) was measured by titration of $10 \mathrm{~mL}$ homogenized fruit flesh juice with $0.1 \mathrm{~N} \mathrm{NaOH}$ to an endpoint of $\mathrm{pH} 8.1$ and expressed as the percentage of citric acid (mod. S compact titrator, Crison Instruments, Barcelona, Spain).

Cactus pear weight loss was calculated on 5 packages for each treatment $(5$ boxes $\times$ 2 treatments) and expressed as the percentage reduction with respect to the initial time, using a two-decimal precision digital balance (Mod. CENT-2 10000, Milan, Italy).

$$
\% \text { Weight loss }=((\mathrm{Wi}-\mathrm{Ws})) / \mathrm{Wi} \times 100
$$

where Wi is the initial weight, and Ws is the weight measured during storage.

Minimally processed cactus pear fruits external color was measured at two opposite points on each fruit using a colorimeter (Chroma Meter CR-400C, Tokyo, Japan). CIE $\mathrm{L}^{*} \mathrm{a}^{*} \mathrm{~b}^{*}$ coordinates were recorded as $\mathrm{L}^{*}$ (lightness), $\mathrm{a}^{*}$ (positive values for reddish colors and negative values for greenish colors), and $b^{*}$ (positive values for yellowish colors and negative values for bluish colors). From these components Chroma $\left(C^{*}\right)$ and Hue angle $\left(h^{\circ}\right)$ were calculated as [19].

$$
\begin{aligned}
C^{*} & =\left(a^{* 2}+b^{* 2}\right)^{1 / 2} \\
h^{\circ} & =\arctan \left(b^{*} / a^{*}\right)
\end{aligned}
$$

\subsection{Headspace Gas Composition}

In-packages, $\mathrm{O}_{2}$, and $\mathrm{CO}_{2}$ partial pressure were measured immediately before quality evaluation, using an $\mathrm{O}_{2}$ and $\mathrm{CO}_{2}$ portable analyzer (Dansensor Checkpoint, Ametek Mocon, Minneapolis, MN, USA) after $0,3,6$ and, 9 days at $5{ }^{\circ} \mathrm{C}$ using 5 packages for each treatment.

\subsection{Nutraceutical Attributes}

The betalain, ascorbic acid content and antioxidant activity of minimally processed cactus pear fruits was assessed soon after coating $(0 \mathrm{~d})$ and at $3(3 \mathrm{~d}), 6(6 \mathrm{~d})$, and $9(9 \mathrm{~d})$ days of storage at $5{ }^{\circ} \mathrm{C}$. For each sampling date and experimental treatment (OFI C and OFI M), three samples were randomly chosen and analyzed.

\subsubsection{Fruit Extract Preparation}

Cactus pear fruit samples were frozen at $-80{ }^{\circ} \mathrm{C}$ until extract preparation. The frozen samples were thawed, chopped, and the seeds were separated from the pulp. The pulp was homogenized, and fruit extracts were prepared as previously described with minor changes [20]. Briefly, ten grams of the whole homogenate were weighed and then extracted with $\mathrm{MeOH}$ using a 1:5 $(w / v)$ ratio. Samples were mixed by vortex for 5 min and sonicated at room temperature for $15 \mathrm{~min}$. The mixtures were allowed to stand for $2 \mathrm{~h}$ at room temperature. After centrifugation $\left(10 \mathrm{~min}\right.$ at $\left.8000 \times g, 4^{\circ} \mathrm{C}\right)$ the supernatants were filtered, portioned, and stored at $-20^{\circ} \mathrm{C}$. The extraction procedure was repeated to obtain three different technical replicates.

\subsubsection{Quantitation of Betalains in Fruit Extracts}

Betanin and indicaxantin in fruit extracts were evaluated spectrophotometrically after separation by gel filtration on a Sephadex G-25 column $(40 \mathrm{~cm} \times 2.2 \mathrm{~cm})$ [21], betanin was quantified by the absorbance at $536 \mathrm{~nm}$, using a molar extinction coefficient of 65,000 [22]. Owing to the overlapping of betanin absorbance with the absorbance of indicaxanthin at $482 \mathrm{~nm}$, the indicaxanthin concentration was determined according to Equation (1) as previously reported [23]:

$$
\text { (indicaxanthin) }(\mu \mathrm{M})=23.8 \mathrm{~A}_{482}-7.7 \mathrm{~A}_{536}
$$

This equation was obtained considering the molar absorbance of indicaxanthin at $482 \mathrm{~nm}\left(\mathrm{~A}_{482}(\right.$ indicaxanthin $\left.)=42,600\right)$ [24] and of betanin at either 536 or $482 \mathrm{~nm}$. 


\subsubsection{DPPH Assay}

Radical-scavenging activity of fruit extracts was evaluated by DPPH (2,2-diphenyl-1picrylhydrazyl) assay. The assay is based on the monitoring of decolorization of a solution of the radical DPPH at $735 \mathrm{~nm}$ [25]. The radical scavenging activity of each sample was expressed as Trolox equivalent (TE) per $100 \mathrm{~g}$ of FW (Fresh Weight). Samples were tested at five different dilutions, and for each sample, the assay was repeated three times.

\subsubsection{Ascorbic Acid Content}

Ascorbic acid in OFI C and OFI M samples was determined by extracting $10 \mathrm{~g}$ of blended fruit sample in $100 \mathrm{~mL}$ metaphosphoric acid $\left(\mathrm{HPO}_{3}\right)$, then filtered through Whatman no 1 filter paper. A volume of $10 \mathrm{~mL}$ from filtered solution was determined volumetrically with the 2-6 dichlorophenol-indophenol reagent until a slightly pink coloration was observed and persisted for $15 \mathrm{~s}$ [26]. The reading of ascorbic acid content was expressed in $\mathrm{mg} / 100 \mathrm{~g}$ FW.

\subsection{Sensory Analysis and Visual Score}

At each sampling date, 5 boxes ( 3 fruits in each) for each treatment (OFI C and OFI M) were subjected to sensory evaluation. The sensory profile was constructed by a panel made of 10 judges ( 5 females and 5 males that regularly ate cactus pears fruits, aged between 25 and 45 years) trained in a few preliminary meetings: by using commercial fruit, the judges generated a list of descriptors. Sensory analysis was focused on firmness, sweetness, acidity, aroma, off-flavor development, and overall acceptance. The different descriptors were quantified using a ten-point intensity scale where digit 1 indicates the descriptor absence while digit 10 the full intensity [7]. The order of presentation was randomized between judges. Water was provided for rinsing between samples.

At each sampling date, 5 boxes ( 3 fruits in each) for each treatment (OFI C and OFI M) were also evaluated by each judge for the visual score. Visual appearance score resulted from the medium value of color, visible structural integrity, and visual appearance [10]. The different descriptors were quantified using a subjective $5-1$ rating scale with $5=$ very good, 4 = good, 3 = sufficient, $2=$ poor (limit of edibility) and $1=$ very poor (inedible) [27]. A score of 3 was the limit of marketability. The order of presentation was randomized between judges.

\subsection{Microbiological Analyses}

Fruit samples (OFI C and OFI M) were analyzed soon after production and after 3, 6, and 9 days of refrigerated storage $\left(5^{\circ} \mathrm{C}\right)$. Fruit samples and mucilage were microbiologically analyzed to investigate their quality, hygiene, and safety aspects. Twenty-five g of OFI C (uncoated control) and OFI M (coated treatment) fruit samples and $10 \mathrm{~mL}$ of mucilage were transferred into sterile plastic bags $\left(\right.$ BagLight ${ }^{R} 400$ Multilayer ${ }^{R}$ bags, Interscience, Saint Nom, France), added with Ringer's solution (Sigma-Aldrich, Milan, Italy) to a ratio 1:10, and homogenized by the stomacher Bag-Mixer 400 (Interscience) for $2 \mathrm{~min}$ at the maximum speed (blending power 4).

All homogenized samples were then subjected to the decimal serial dilution procedure. Cell suspensions were plated and incubated as follows: Total Mesophilic Microorganisms (TMM) on Plate Count Agar (PCA), incubated at $30^{\circ} \mathrm{C}$ for $72 \mathrm{~h}$; Total Psychrotrophic Microorganisms (TPM) on PCA, incubated at $7{ }^{\circ} \mathrm{C}$ for 7 days; pseudomonads on Pseudomonas Agar Base (PAB) added with Cetrimide Fucidin Cephaloridine (CFC) supplement, incubated at $25^{\circ} \mathrm{C}$ for $48 \mathrm{~h}$; members of the Enterobacteriaceae family on Violet Red Bile Glucose Agar (VRBGA), incubated at $37^{\circ} \mathrm{C}$ for $24 \mathrm{~h}$; Listeria monocytogenes on Listeria Selective Agar Base (LSAB) added with SR0140E supplement, incubated at $37^{\circ} \mathrm{C}$ for $48 \mathrm{~h}$; and yeasts on Yeast extract Peptone Dextrose (YPD) agar supplemented with $0.1 \mathrm{~g} / \mathrm{L}$ chloramphenicol to avoid bacterial growth, incubated at $28{ }^{\circ} \mathrm{C}$ for $48 \mathrm{~h}$. All media and supplements were purchased from Oxoid (Milan, Italy). All plate counts were performed in triplicate. 


\subsection{Statistical Analyses}

All data were submitted to one-way analysis of variance (ANOVA) and means were separated with Tukey's test at $p \leq 0.05$. The statistical analysis was carried out using Systat 10 (Systat, Chicago, IL, USA).

\section{Results}

3.1. Quality Parameters: Firmness, Soluble Solids Content, Titratable Acidity, Color, and Weight Loss

Fruit firmness decreased significantly in OFI C and OFI M samples during storage (Table 1). Significant differences between OFI C and OFI M samples occurred from the third day of storage at $5{ }^{\circ} \mathrm{C}$ until the end of the storage (Table 1). OFI C samples showed the highest decrease with a loss of firmness of $51 \%$ from $\mathrm{T} 0$ to the end of the cold storage period (Table 1). Otherwise, OFI M showed the highest fruit firmness value at end of the cold storage with no significant loss of firmness of $14 \%$ from the beginning to the end of the cold storage period, showing the effectiveness of OFI mucilage coating in terms of maintaining fruit cell structure (Table 1). TSS and TA values remained stable in both OFI C and OFI M samples during storage (Table 1). TSS showed a slight no significant increase in OFI C samples, while TA values remained stables in both samples during cold storage, no significant differences between OFI C and OFI M occurred for TSS and TA (Table 1).

Table 1. Changes in firmness, total soluble solids (TSS) and titratable acidity (TA) in minimally processed O. ficus-indica fruits non-treated (OFI C) and treated with mucilage (OFI M) during cold storage ( 9 days at $\left.5{ }^{\circ} \mathrm{C}\right)$. Different lowercase letters indicate significant differences at $p \leq 0.05$ between the treatments in each sampling date. Data are the mean $\pm \mathrm{SE}(n=5)$.

\begin{tabular}{|c|c|c|c|c|c|c|}
\hline \multirow{3}{*}{$\begin{array}{c}\text { Storage Time } \\
\text { (days })\end{array}$} & \multicolumn{2}{|c|}{ Firmness } & \multicolumn{2}{|c|}{ Total Soluble Solids (TSS) } & \multicolumn{2}{|c|}{ Titratable Acidity (TA) } \\
\hline & \multicolumn{2}{|c|}{$(N)$} & \multicolumn{2}{|c|}{$\left({ }^{\circ}\right.$ Brix $)$} & \multicolumn{2}{|c|}{ (g citric acid $100 g^{-1} \mathrm{FW}$ ) } \\
\hline & OFI C & OFI M & OFI C & OFI M & OFI C & OFI M \\
\hline T0 & $18.50 \pm 0.71 \mathrm{a}$ & $18.50 \pm 0.71 \mathrm{a}$ & $13.95 \pm 0.42$ & $13.95 \pm 0.42$ & $0.058 \pm 0.002$ & $0.058 \pm 0.002$ \\
\hline T3 & $15.41 \pm 0.89 \mathrm{~b}$ & $17.97 \pm 0.92 \mathrm{a}$ & $14.75 \pm 0.35$ & $14.11 \pm 0.41$ & $0.053 \pm 0.003$ & $0.054 \pm 0.001$ \\
\hline $\mathrm{T} 6$ & $13.62 \pm 0.84 \mathrm{~b}$ & $16.32 \pm 0.91 \mathrm{a}$ & $14.91 \pm 0.59$ & $14.32 \pm 0.51$ & $0.052 \pm 0.002$ & $0.053 \pm 0.003$ \\
\hline T9 & $9.11 \pm 0.97 b$ & $15.93 \pm 0.88 \mathrm{a}$ & $14.95 \pm 0.47$ & $14.42 \pm 0.41$ & $0.051 \pm 0.002$ & $0.053 \pm 0.001$ \\
\hline
\end{tabular}

The mucilage coating treatment significantly decreased weight loss percentage during cold storage in OFI M compared to OFI C samples (Figure 1). OFI C samples showed a weight loss from 2 to 2.5 times higher than OFI M samples during cold storage, and differences between coated and uncoated fruit were significant starting from 1 day until the end of the cold storage period (Figure 1).

Fruit flesh brightness $\left(\mathrm{L}^{*}\right)$ was similar in OFI C and OFI M fruit at the time of treatment. OFI C fruit showed a continuous decrease of flesh brightness, with lower values than OFI $\mathrm{M}$ fruit during the entire cold storage period (from 0 to 9 days of storage at $5^{\circ} \mathrm{C}$ ) (Figure 2). OFI M showed a slight decrease during storage, with a loss of $9 \%$ of flesh brightness from T0 to 9 days of cold storage, while OFI C showed a sharply decrease with a loss of $25 \%$ of flesh brightness from the beginning to the end of the cold storage period (Figure 2). The mucilage coating positively affected fruit quality parameters reduced weight loss, and improved fruit brightness.

\subsection{Headspace Gas Composition}

In-package atmosphere was significantly affected by storage time in both treatments (OFI C and OFI M). During cold storage, a decrease in $\mathrm{O}_{2}$ and an increase in $\mathrm{CO}_{2}$ inpackages levels were observed for both OFI C and OFI M packaging (Figure 3A,B). OFI $\mathrm{C}$ samples showed a significantly higher level of $\mathrm{CO}_{2}$ than OFI M during storage, OFI C samples showed an in-package $\mathrm{CO}_{2}$ concentration almost twice than in OFI $\mathrm{M}$ ones after 9 days of cold storage (Figure 3A). OFI M samples showed a significantly higher level of $\mathrm{O}_{2}$ than OFI $\mathrm{C}$ during storage with values 2 times higher than in OFI $C$ samples at 
the end of the cold storage period (Figure 3B). After 9 days of cold storage, the $\mathrm{O}_{2} / \mathrm{CO}_{2}$ in-packages concentration ( $\mathrm{kPa}$ ) in OFI C and, OFI M was about 6/6, and $13 / 3$, respectively (Figure $3 \mathrm{~A}, \mathrm{~B}$ ). OFI $\mathrm{C}$ fruits showed a higher respiration rate during cold storage than OFI M fruits, and OFI C samples showed a loss in terms of in-package $\mathrm{O}_{2}$ concentration of $60 \%$ from the beginning to the end of the cold storage, whereas the in-package $\mathrm{O}_{2}$ concentration loss in OFI M was of 35\% from the beginning to the end of the cold storage period (Figure $3 \mathrm{~A}, \mathrm{~B}$ ). The mucilage coating provided a barrier for OFI M samples, reducing the respiration rate during the cold storage period.

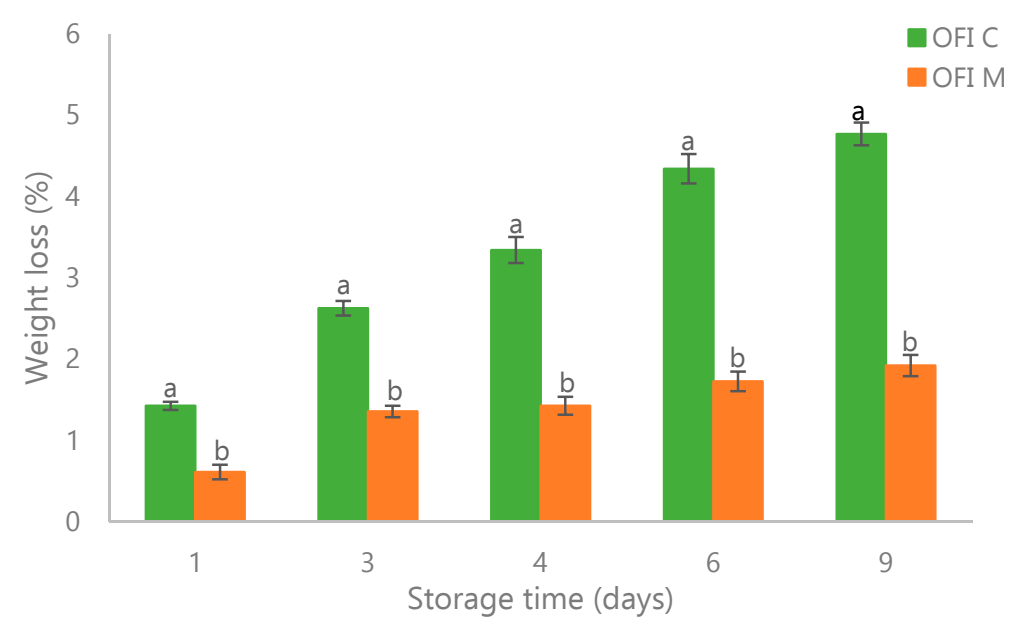

Figure 1. Changes in weight loss (\%) in minimally processed O. ficus-indica non-treated fruit (OFI C) and treated fruits with mucilage (OFI M) over 9 days at $5{ }^{\circ} \mathrm{C}$. Different lowercase letters indicate significant differences at $p \leq 0.05$ between the treatments in each sampling date. Data are the mean \pm SE (Vertical bars represent standard error; $n=5$ ).

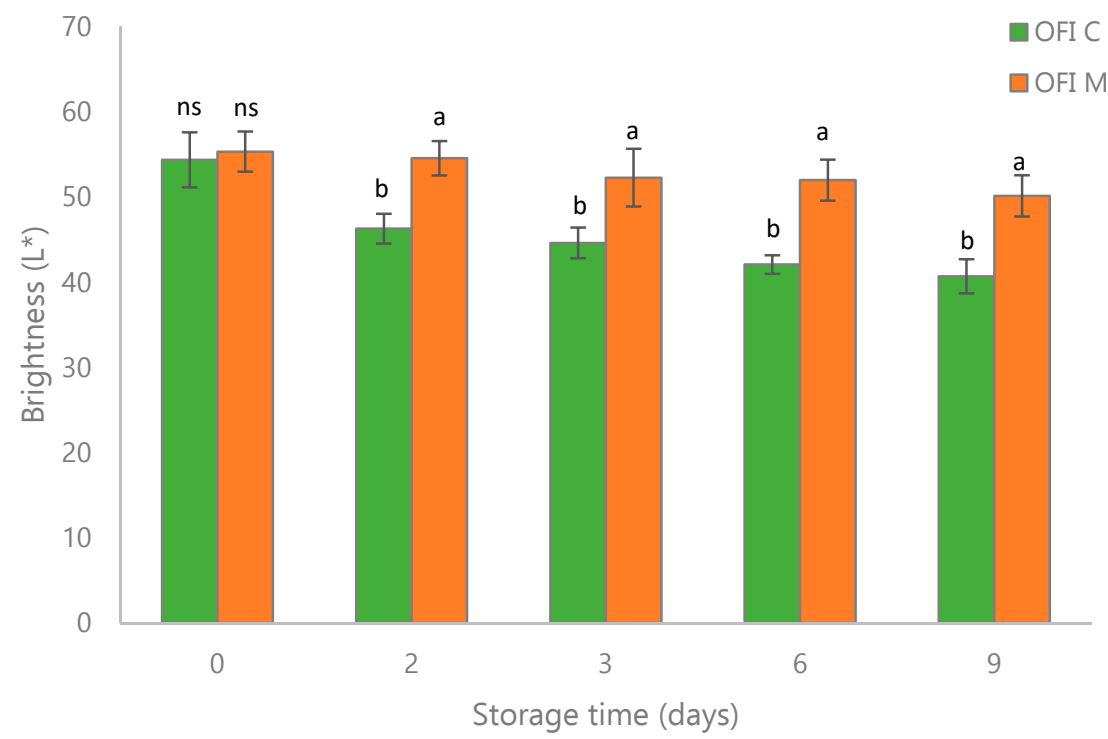

Figure 2. Changes in brightness $\left(\mathrm{L}^{*}\right)$ in minimally processed $O$. ficus-indica fruits non-treated (OFI C) and treated with mucilage (OFI M) during cold storage $\left(9\right.$ days at $\left.5^{\circ} \mathrm{C}\right)$. Different lowercase letters indicate significant differences at $p \leq 0.05$ between the treatments in each sampling date. Data are the mean \pm SE (Vertical bars represent standard error; $n=5$ ). 

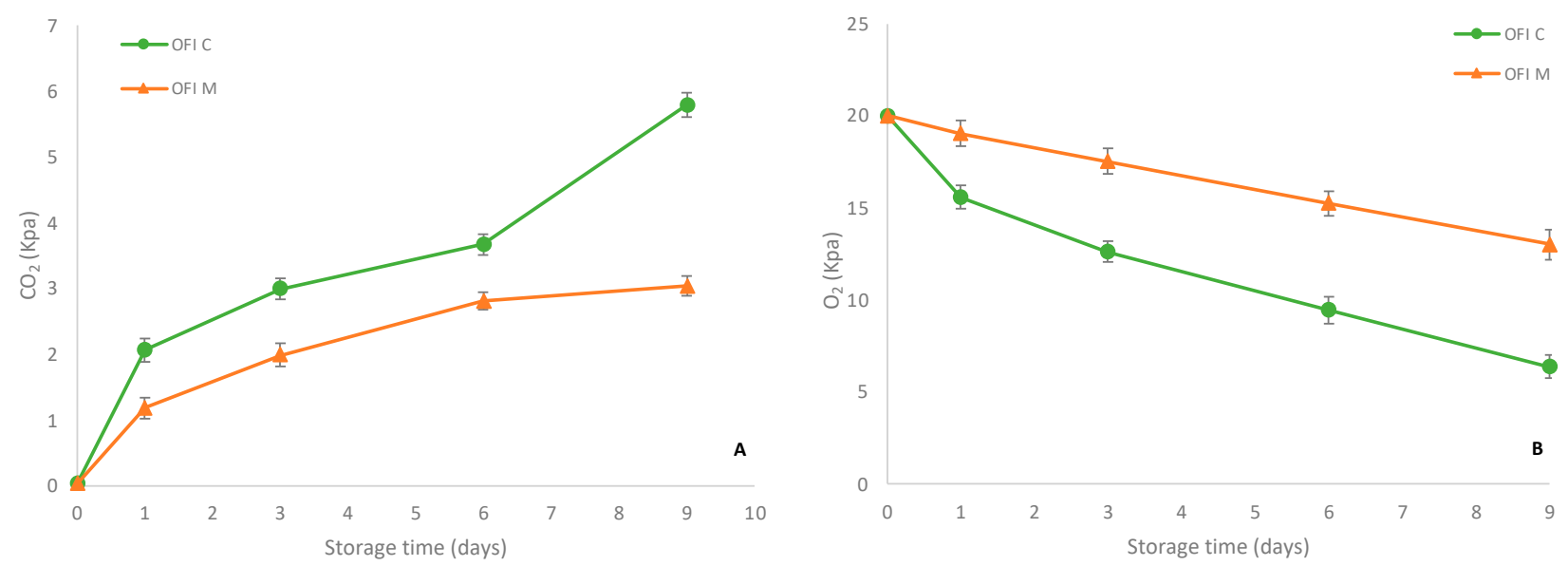

Figure 3. Concentrations of $\mathrm{CO}_{2}(\mathbf{A})$ and $\mathrm{O}_{2}(\mathbf{B})$ in minimally processed $\mathrm{O}$. ficus-indica non-treated fruit (OFI C) and treated fruits with mucilage (OFI M) during cold storage (9 days at $5^{\circ} \mathrm{C}$ ). Data are the mean $\pm \mathrm{SE}$ (bars represent standard error of the means; $n=5)$.

\subsection{Bioactive Compounds and Radical Scavenging Activity}

Indicaxantin, ascorbic acid content, and antioxidant activity (DPPH) were significantly affected by storage time and treatment (Table 2). Indicaxantin content showed a timedependent sharp decrease in OFI C samples, showing a loss of $15 \%$ from the beginning to the end of the cold storage period (Table 2). The indicaxanthin loss in terms of indicaxantin content in OFI C samples appeared after 3 days of storage and then was stable until the end of the cold storage period, with a loss of $15 \%$ from the beginning to the end of the cold storage period (Table 2). Indicaxantin content was significantly higher in OFI M samples than in OFI C ones during the storage time in each sampling date, showing values 1.3 times higher at end of the cold storage period (Table 2). Betanin content showed a slight decrease in OFI C samples, but otherwise was stable in OFI M samples during the cold storage period (Table 2). In any case, betanin content was higher (no significant) in OFI M samples compared to OFI $\mathrm{C}$ from day 3 to day 9 of storage at $5{ }^{\circ} \mathrm{C}$ (Table 2). Ascorbic acid showed a gradual but moderate decline during storage in both samples (uncoated and coated), with losses of about $18 \%$, and $6 \%$ in OFI C and OFI M samples, respectively at the end of the cold storage period (Table 2). Ascorbic acid content was significantly higher in OFI M samples than in OFI C from day 3 to day 9 of storage at $5{ }^{\circ} \mathrm{C}$ (Table 2).

Table 2. Changes in Indicaxantin, Betanin, Ascorbic Acid and DPPH in minimally processed O. ficus-indica fruits non-treated (OFI C) and treated with mucilage (OFI M) during cold storage ( 9 days at $5{ }^{\circ} \mathrm{C}$ ). Different lowercase letters indicate significant differences at $p \leq 0.05$ between the treatments in each sampling date. Data are the mean $\pm \operatorname{SE}(n=5)$.

\begin{tabular}{|c|c|c|c|c|c|c|c|c|}
\hline \multirow{3}{*}{$\begin{array}{c}\text { Storage Time } \\
\text { (days })\end{array}$} & \multirow{2}{*}{\multicolumn{2}{|c|}{$\begin{array}{c}\text { Indicaxantin } \\
\left(m g 100 g^{-1} \mathrm{FW}\right)\end{array}$}} & \multicolumn{2}{|c|}{ Betanin } & \multicolumn{2}{|c|}{ Ascorbic Acid } & \multicolumn{2}{|c|}{ DPPH } \\
\hline & & & (mg 100 & $\left.{ }^{-1} F W\right)$ & $(m g) 100$ & $\left.{ }^{-1} F W\right)$ & (mmol TE & $\left.0 g^{-1} F W\right)$ \\
\hline & OFI C & OFI M & OFI C & OFI M & OFI C & OFI M & OFI C & OFI M \\
\hline T0 & $8.12 \pm 0.32 \mathrm{a}$ & $8.93 \pm 0.33 a$ & $0.45 \pm 0.02 \mathrm{a}$ & $0.49 \pm 0.02 \mathrm{a}$ & $30.5 \pm 0.21 \mathrm{a}$ & $30.5 \pm 0.21 \mathrm{a}$ & $4.61 \pm 0.32 \mathrm{a}$ & $4.67 \pm 0.13 \mathrm{a}$ \\
\hline T3 & $6.86 \pm 0.28 b$ & $8.29 \pm 0.32 \mathrm{a}$ & $0.38 \pm 0.04 a$ & $0.46 \pm 0.03 a$ & $27.3 \pm 0.23 b$ & $29.4 \pm 0.34 \mathrm{a}$ & $4.54 \pm 0.18 \mathrm{a}$ & $4.80 \pm 0.28 \mathrm{a}$ \\
\hline T6 & $6.91 \pm 0.17 b$ & $8.27 \pm 0.23 \mathrm{a}$ & $0.38 \pm 0.05 a$ & $0.45 \pm 0.03 \mathrm{a}$ & $26.8 \pm 0.15 b$ & $29.1 \pm 0.30 \mathrm{a}$ & $3.40 \pm 0.20 b$ & $4.71 \pm 0.47 \mathrm{a}$ \\
\hline T9 & $6.89 \pm 0.21 b$ & $8.89 \pm 0.51 \mathrm{a}$ & $0.37 \pm 0.02 \mathrm{a}$ & $0.49 \pm 0.01 \mathrm{a}$ & $25.1 \pm 0.21 b$ & $28.8 \pm 0.15 a$ & $2.24 \pm 0.23 b$ & $4.82 \pm 0.33 \mathrm{a}$ \\
\hline
\end{tabular}

The radical scavenging activity in OFI $C$ samples decreased during storage, showing a loss of $51 \%$ from the beginning to the end of the cold storage period (Table 2). The loss in terms of DPPH in OFI C samples appeared after 6 days of storage decreasing until the end of the cold storage period (Table 2). Otherwise, DPPH assay values in OFI M samples were almost stable during storage, showing values 2.1 times higher than in OFI C ones at end of the cold storage period (Table 2). 


\subsection{Evolution of Microbiological Parameters}

Table 3 shows the microbiological characteristics of minimally processed cactus pear fruit samples with (OFI M) and without (OFI C) mucilage coating. At the beginning of the trial, a sample of mucilage used for coating was analyzed that did not evidence the presence of any of the microbial groups objects of investigation. None of the analyzed samples had detectable levels of L. monocytogenes. According to Tukey's test, significant statistical differences between the fruits processed with and without film coatings appeared at 3 and $6 \mathrm{~d}$ of refrigerated storage. OFI $\mathrm{M}$ samples showed a concentration of about 1 Log cycle lower than OFI C fruits for all microbial groups investigated, during the entire period of observation. The concentration of aerobic bacteria (TMM, TPM, and Pseudomonas) and yeasts increased during storage. The highest load was registered for yeasts in OFI C samples on the 9th day.

Table 3. Microbial loads of minimally processed uncoated O. ficus-indica (OFI C) and coated (OFI M) fruits during cold storage $\left(9\right.$ days at $\left.5{ }^{\circ} \mathrm{C}\right)$.

\begin{tabular}{|c|c|c|c|c|c|c|c|c|c|}
\hline \multirow{2}{*}{ Microorganisms } & \multicolumn{4}{|c|}{ OFI C } & \multicolumn{4}{|c|}{ OFI M } & \multirow{2}{*}{$\begin{array}{c}\text { Statistical } \\
\text { Significance }\end{array}$} \\
\hline & $\mathbf{0 d}$ & $3 \mathrm{~d}$ & $6 \mathrm{~d}$ & $9 \mathrm{~d}$ & $0 \mathrm{~d}$ & $3 \mathrm{~d}$ & $6 \mathrm{~d}$ & $9 \mathrm{~d}$ & \\
\hline TMM & $<2 \mathrm{a}$ & $3.9 \pm 0.2 \mathrm{a}$ & $4.9 \pm 0.2 \mathrm{a}$ & $5.7 \pm 0.2 \mathrm{a}$ & $<2 \mathrm{a}$ & $2.7 \pm 0.2 \mathrm{~b}$ & $3.5 \pm 0.3 b$ & $4.8 \pm 0.2 b$ & $* * *$ \\
\hline TPM & $<2 \mathrm{a}$ & $2.8 \pm 0.2 \mathrm{a}$ & $3.7 \pm 0.2 \mathrm{a}$ & $4.4 \pm 0.3 \mathrm{a}$ & $<2 \mathrm{a}$ & $2.0 \pm 0.0 \mathrm{~b}$ & $2.9 \pm 0.1 b$ & $3.5 \pm 0.2 b$ & $* * *$ \\
\hline Pseudomonads & $<2 \mathrm{a}$ & $3.7 \pm 0.3 \mathrm{a}$ & $4.5 \pm 0.2 \mathrm{a}$ & $4.9 \pm 0.3 \mathrm{a}$ & $<2 \mathrm{a}$ & $2.1 \pm 0.1 b$ & $2.9 \pm 0.3 b$ & $3.7 \pm 0.2 b$ & $* * *$ \\
\hline Enterobacteriaceae & $<2 \mathrm{a}$ & $<2 \mathrm{a}$ & $2.7 \pm 0.1 \mathrm{a}$ & $3.5 \pm 0.3 b$ & $<2 \mathrm{a}$ & $<2 \mathrm{a}$ & $<2 \mathrm{~b}$ & $2.3 \pm 0.1 b$ & * \\
\hline Yeasts & $<2 \mathrm{a}$ & $3.6 \pm 0.4 \mathrm{a}$ & $4.6 \pm 0.2 \mathrm{~b}$ & $5.8 \pm 0.1 b$ & $<2 \mathrm{a}$ & $2.5 \pm 0.3 b$ & $3.2 \pm 0.1 b$ & $4.3 \pm 0.2 \mathrm{a}$ & $* *$ \\
\hline
\end{tabular}

Units are $\log$ CFU/g. Results indicate mean values \pm S.D. of four plate counts (carried out in duplicate for two independent productions); data within a line followed by the same letter between OFI $C$ and OFI $M$ at the same day of refrigerated storage are not significantly different according to Tukey's test. $p$ value: ${ }^{*} p \leq 0.05 ;{ }^{* *} p \leq 0.01 ; * * * \leq 0.001$; Abbreviations: TMM, total mesophilic microorganisms; TPM, total psychrotrophic microorganisms.

The levels of members of Enterobacteriaceae family were below the detection limit for both treatments after $3 \mathrm{~d}$ of storage, but they were detected at $6 \mathrm{~d}$ of refrigerated storage in OFI C samples and increased up to $3.5 \mathrm{Log} \mathrm{CFU} / \mathrm{g}$ at $9 \mathrm{~d}$. In the case of OFI M fruits, Enterobacteriaceae were only detected on the 9 th day.

\subsection{Sensory Analysis and Visual Score}

Uncoated (OFI C) and coated (OFI M) cactus pear fruit samples were subjected to sensory evaluation on each sampling date. Minimally processed cactus pear fruits sensory profiles were positively affected by mucilage coating; panelists preferred OFI M samples in each sampling date with mean scores 1.7 higher than OFI $C$ during the cold storage period (data not shown).

OFI M samples showed mean scores 1.2 higher in terms of sensory evaluation than OFI C samples after 3 days of storage at $5{ }^{\circ} \mathrm{C}$ (Figure 4). Panelists perceived the largest difference in the aroma, firmness and taste descriptors in OFI M samples, with scores 1.4 almost higher than OFI $\mathrm{C}$ ones and in the off-flavor descriptor, with scores four times lower than OFI C ones (Figure 4).

Additionally, at the end of the storage (9 days), OFI M samples were preferred by judges showing the highest scores in almost all sensorial parameters, OFI M samples obtained sensory evaluation mean scores 1.7 higher than OFI C ones (Figure 5). Panelists perceived off-flavor in OFI C samples from 3 days to 9 days at $5{ }^{\circ} \mathrm{C}$ (Figures 4 and 5), while the perception of this descriptor was almost absent in OFI M samples in each sampling date (Figures 4 and 5).

The sensory analysis showed that judges had a higher preference for coated samples at the end of the cold storage period. The mucilage coating did not negatively affect the natural taste of cactus pear fruits, which is an important aspect regarding the use of edible coatings when taste modification is undesirable. MA coating has exalted some impor- 
tant parameters, as well as aroma, sweetness, and taste that are particularly appreciated by consumers.

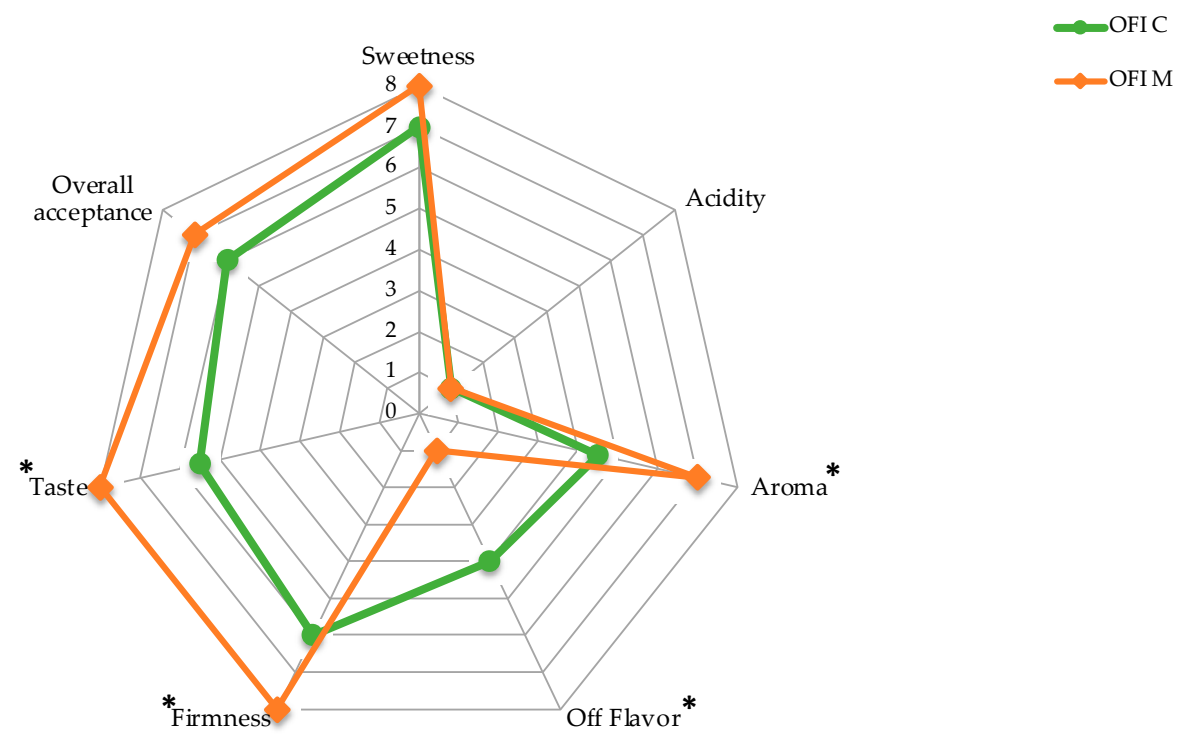

Figure 4. Sensorial analysis of minimally processed $O$. ficus-indica non-treated fruit (OFI C) and treated fruits with mucilage (OFI M) after 3 days of cold storage at $5{ }^{\circ} \mathrm{C}$. ${ }^{*}$ indicate significant differences (Tukey's test at $p \leq 0.05$ ) between the treatments (OFI C and OFI M, $n=5$ ).

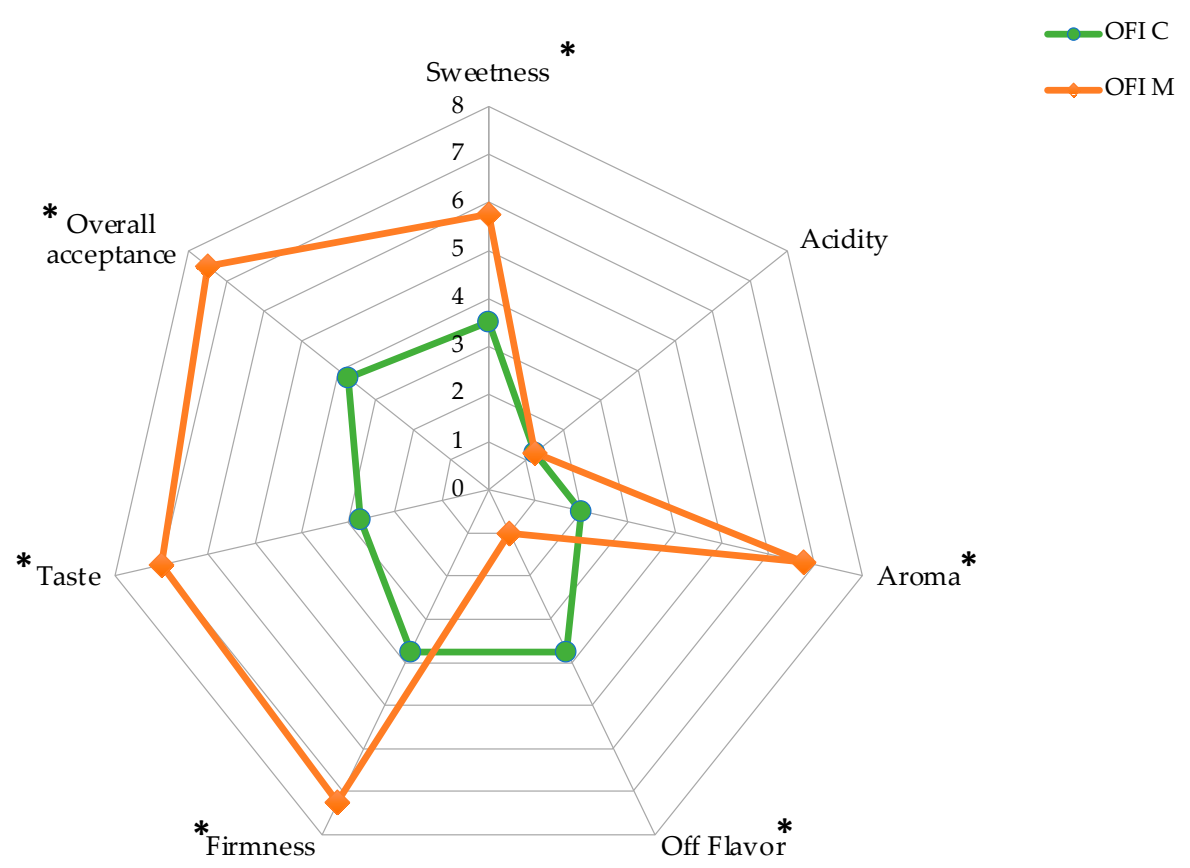

Figure 5. Sensorial analysis of minimally processed O. ficus-indica non-treated fruit (OFI C) and treated fruits with mucilage $(\mathrm{OFI} \mathrm{M})$ at the end of cold storage $\left(9\right.$ days at $5{ }^{\circ} \mathrm{C}$. $){ }^{*}$ indicate significant differences (Tukey's test at $p \leq 0.05$ ) between the treatments (OFI C and OFI M, $n=5$ ).

The visual score of OFI C samples significantly decreased during storage, OFI C samples had a severe descending trend, that dropped below the limit of marketability and edibility after six days and nine days of storage, respectively, whereas the OFI M samples showed visual scores above the limit of marketability and edibility during all of the cold storage period (Figure 6). OFI M samples showed a visual score of 2.3 higher than OFI C ones at the end of the cold storage period (Figure 6), confirming that the mucilage coating positively affects the overall fruit appearance. 


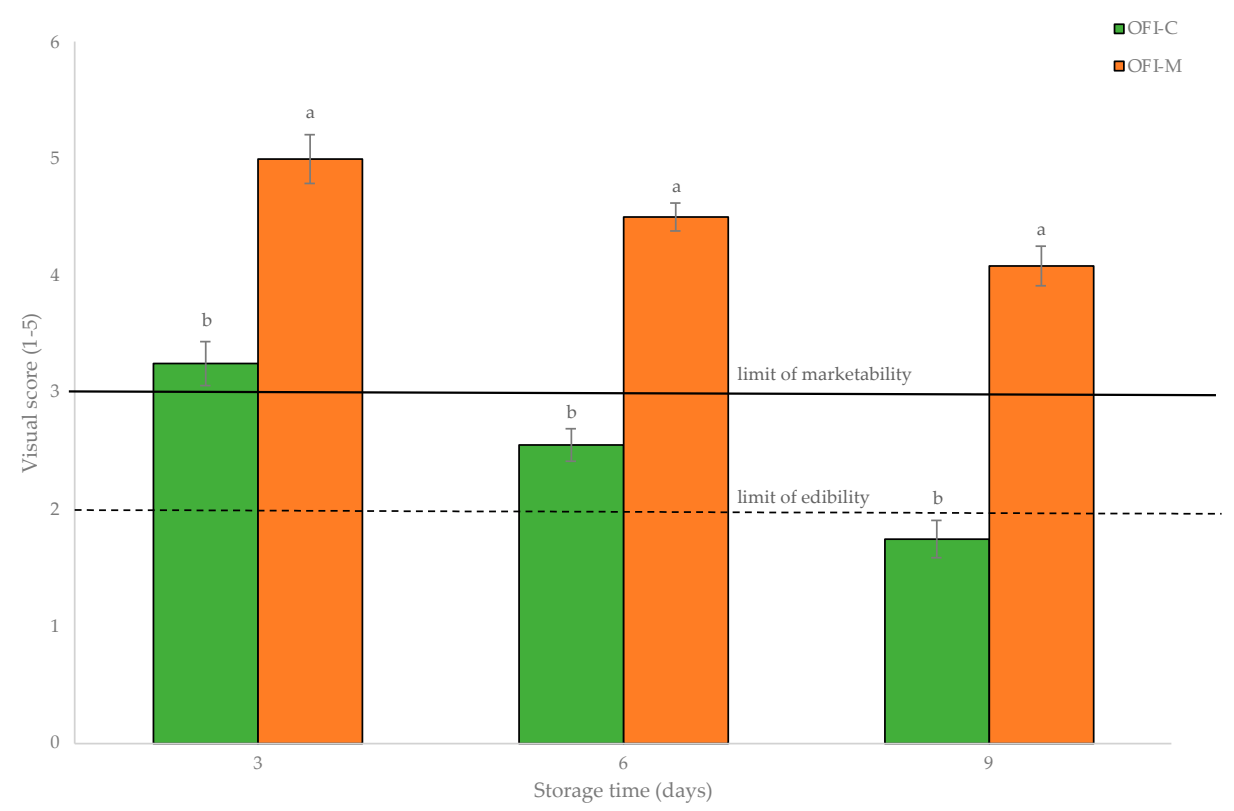

Figure 6. Visual score of minimally processed O. ficus-indica non-treated fruit (OFI C) and treated fruits with mucilage (OFI M) during cold storage ( 9 days at $5{ }^{\circ} \mathrm{C}$ ). Different lowercase letters indicate significant differences (Tukey's test at $p \leq 0.05$ ) between the treatments in each sampling date. Data are the mean \pm SE (Vertical bars represent standard error; $n=5)$. [ $(5=$ very good, $4=$ good, $3=$ fair (limit of marketability), 2 = poor (limit of edibility) and 1 = very poor (inedible)].

\section{Discussion}

Cactus pear is a non-climacteric fruit, characterized by a quite short postharvest life due to an intrinsic predisposition to physical damage as well as high metabolic activity; fruit firmness changes during postharvest storage life are usually due to dehydration and changes in the components of the middle lamella and primary cell wall, which causes fruit softening [28]. Indeed, the combined action of cell wall hydrolyzing enzymes results in loss of integrity of the cell wall by the disassembly of the cellulose-hemicellulose network [29].

Fruit texture is a critical quality attribute in cactus pears as tissue softening occurs at a very high rate with fruit ripening, the enzymatic reactions due to fruit processing operations (peeling, slicing, etc.), and leads to rapid losses in firmness [5]. In our study, the highest fruit firmness values were measured on OFI M samples during the cold storage period, showing the ability of mucilage to preserve fruit structure (Table 1). This effect on fruit firmness could be attributed to calcium content in Opuntia ficus-indica (OFI) mucilage that preserves fruit integrity cell wall and middle lamella, by interacting with the pectic acid in the cell walls to form calcium pectate [13]. Indeed, previous studies reported that fruit calcium pre- and postharvest treatments increased calcium content in the fruit, and maintained firmness in strawberry [30], fig [31], guava fruits [32], peach [33] and, ber fruits [29].

Our study showed the positive effect of polysaccharidic coatings, such as cactus pear mucilage coatings, that act as a barrier reducing losses on firmness, as reported in previous studies [34]. OFI M samples reported firmness values 1.7 higher than OFI $C$ at end of the cold storage period, enhanced resistance to mechanical damage during storage and, thereby, reducing economic losses during the food chain.

One of the most beneficial effects of fruit film packaging and coating is the maintenance of high RH inside the package, cactus pear mucilage acts as a barrier to water transfer, reducing weight loss $[6,33]$; results of our study indicate that the weight loss of minimally processed cactus pear fruits, was strongly influenced by OFI mucilage coating, OFI C samples showed weight loss values 2.5 higher than OFI M ones (Figure 1). OFI mucilage coating reduced transpiration and weight loss on cactus pear fruits, like results reported on strawberry [7,14], kiwifruit [10], and breba fig [13]. 
Color is one of the main factors that affect fruit consumer choice and acceptability, and in minimally processed fruit, changes in color can occur due to the synthesis of new pigments, discoloration, or browning of wounded or bruised surfaces or both [5]. Previous studies showed a slight decrease in fruit brightness and an increase in darkening in white and red peeled cactus pears, respectively [35]; while Allegra et al. [36] did not find important changes in flesh color of yellow minimally processed cactus pear fruits during storage. In our study, OFI C samples brightness decreased significantly during cold storage, like that obtained by Palma et al. [5], while OFI M did not result in a significant change in brightness during cold storage and had 1.2 times more brightness than OFI C at end of the cold storage period (Figure 2). OFI C samples showed the same behavior reported by Palma et al. [5]. Fruit color decrease is probably correlated to betalains content changes [37], and in our study, the decrease of betalains content was strictly correlated to the loss in brightness in uncoated cactus pear samples during storage.

Cactus mucilage has the potential to act as an effective barrier against gaseous exchange between the environment and coated fruit by reducing $\mathrm{O}_{2}$ permeability and promoting $\mathrm{CO}_{2}$ accumulation in the atmosphere around the fruit [34]; as reported by previous studies [5,36] in-package $\mathrm{CO}_{2}$ and $\mathrm{O}_{2}$ values increased and decreased (Figure 3A,B), respectively, during the cold storage period in both treatments (OFI C and OFI M). In-package atmosphere values fluctuated between 0.03 and $5.80 \mathrm{kPa}$ in OFI C samples and $0.03 \mathrm{kPa}$ and 3.04 in OFI M samples for $\mathrm{CO}_{2}$ and between 20 and $6.4 \mathrm{kPa}$ in OFI $\mathrm{C}$ and between 20 and $13.0 \mathrm{kPa}$ in OFI M samples for $\mathrm{O}_{2}$ from the beginning to the end of the cold storage period (Figure 3A,B). Differences among treatments (OFI C and OFI M) were consistent during storage with a significant reduction of the respiration rate of coated fruits, confirming the gas barrier properties of the mucilage on the fruits.

The yellow indicaxanthin and the purple-red betanin are the characteristic pigments of the cactus pear [23]. Betalains and ascorbic acid are important nutraceutical components of cactus pears that give the fruit a peculiar antioxidant capacity [5]. Storage temperature, in-package atmosphere composition, antioxidant compounds and fruit maturity stage could all stimulate synthesis and affect losses content of betacyanins and betaxanthins during storage [5]. Low temperature combined with reduced levels of $\mathrm{O}_{2}$ stimulated the synthesis of both pigments, in our study betanin and indicaxanthin did not increase during storage, it was probably due to the $\mathrm{O}_{2}$ in-package partial pressure that was not low enough to stimulate new pigment synthesis, as reported by Palma et al. [5]. Betalain content is also reported to increase with fruit maturity, reaching the maximum concentration at full maturity but before full skin coloration. Indicaxanthin and betanin content were significantly higher in OFI M samples than in OFI C ones, showing a positive effect of mucilage coating on the nutraceutical fruit value during cold storage (Table 2).

Usually, ascorbic acid content decreases during storage in most horticultural products, the degradation rates depending on genotype, maturity stage, and storage conditions. In minimally processed fruits, due to wounding that cause fruit physical injuries, the degradation rate can be particularly high. However, in the case of cactus pears, the processing operations normally being limited to peeling, the impact of wounding is expected to be moderate [5]. Vitamin C degradation is also affected by in-package gas atmosphere, as low oxygen levels associated with low storage temperature may reduce the losses [38]. In our study, the mucilage coating significantly reduced the ascorbic acid content losses during storage, OFI M samples showed losses 3 times lower than in OFI C ones, from the beginning to the end of the cold storage period ( $6 \%$ vs. $18 \%$ ) (Table 2).

The antioxidant capacity after the processing operations could be increased by some factors (i.e., phenols, betalains, vitamin C) and decreased by others, and its trend would reflect the contribution given by each individual factor [5]. In our study, mucilage coating showed a positive effect on minimally processed cactus pear fruits radical scavenging activity (DPPH) after 6 days of cold storage, indeed, OFI C samples showed a sharply decreased from days 6 until the end of the cold storage; while DPPH was almost stable in OFI M samples during storage (Table 2). 
Cactus pear is considered a highly perishable fruit due to its susceptibility to microbial spoilage, since its pulp exhibits an almost neutral $\mathrm{pH}$ (5.6-6.5) and a high content in total soluble solids (ranging from 11 to $17^{\circ}$ brix) [39-41]. Therefore, it is important to monitor the microbial composition of these fruits during handling or processing to predict their spoilage [42]. The samples analyzed in this study did not host L. monocytogenes, which is one of the main human pathogens associated with minimally processed fruits and vegetables $[43,44]$. Listeriosis is reported as the third leading cause of death from foodborne illness [45].

OFI M samples showed a concentration of about 1 Log cycle lower than OFI C fruits for all microbial groups investigated, during the entire period of observation. The microbial spoilage in fresh-cut fruits is usually detected by consumers when aerobic bacteria, such as TPM and Pseudomonas, and yeasts reach levels above $7 \mathrm{Log}(\mathrm{CFU} / \mathrm{g})$ and $5 \mathrm{Log}(\mathrm{CFU} / \mathrm{g})$, respectively [46]. However, in our work, barely yeast populations showed a load higher than $5 \mathrm{Log}$ CFU/g only in OFI C fruits after $9 \mathrm{~d}$ of storage. Regarding members of Enterobacteriaceae family, that are considered potential pathogenic microorganisms [47], OFI $M$ showed a significantly lower development than OFI C samples during the entire period of observation. Our results highlighted that the application of O. ficus-indica mucilage, although not able to inhibit microbial growth, significantly limited their development on cactus pear fruits.

The sensory analysis showed that judges preferred mucilage-coated samples at the end of the cold storage period as reported by previous studies in strawberry [7,14], kiwifruit [10], and breba fig [13]. OFI M samples were preferred by the panelist in all the descriptors that gave scores of 7 and 8 to overall acceptance, respectively, after 3 and 9 days of cold storage $\left(5^{\circ} \mathrm{C}\right)$, while OFI $\mathrm{C}$ samples get scores of 6 and 4 in overall acceptance, respectively, after 3 and 9 days of cold storage $\left(5^{\circ} \mathrm{C}\right)$ (Figures 4 and 5). Furthermore, the mucilage coating did not negatively affect the natural taste of minimally processed cactus pear fruits, as none of the panelists could discern any "off-flavor" in OFI M samples, which is an important aspect regarding the use of edible coatings when taste modification is undesirable. OFI mucilage coating has exalted some important parameters, as well as firmness, aroma, sweetness, and taste that are particularly appreciated by consumers (Figures 4 and 5).

OFI $M$ fruits had the highest visual quality scores until the end of the cold storage period, and they were still above the marketability and edibility threshold during the storage, while OFI C fruits were marketable and edible until the first 6 days of storage (Figure 6). As reported by previous studies [7,14], mucilage coating positively affected the fruit overall quality, visual quality scores of coated fruits did not significantly change during cold storage, while they rapidly decreased in uncoated ones (Figure 6).

\section{Conclusions}

The aim of our study was to assess the effects of $O$. ficus-indica mucilage-based coating on quality, nutraceutical value, microbiological growth, and sensorial parameters of minimally processed cactus pear fruits during cold storage.

Our data showed a significant effect of mucilage coating on preserving quality, nutritional value, sensorial parameters, and improving postharvest life of minimally processed cactus pear fruits. O. ficus-indica mucilage had a barrier effect on cactus pear minimally processed fruit during cold storage, reflected by the lower weight loss, the higher firmness, and the lower respiration rate of coated samples than uncoated ones, after 9 days of storage at $5{ }^{\circ} \mathrm{C}$. This treatment could reduce economic losses due to spoilage caused by mechanical damage during handling, processing, and transportation of cactus pear fresh-cut. Total soluble solid content, betalains, and ascorbic acid content were higher in minimally processed cactus pear fruits than uncoated ones during storage, showing the positive effect of mucilage coating on the nutritional and nutraceutical fruit value during cold storage.

Visual quality and sensorial analysis showed that judges had a higher preference for coated samples at the end of the cold storage period. Furthermore, the mucilage coating did not negatively affect the natural taste of minimally processed cactus pear fruits, which 
is an important aspect regarding the use of edible coatings when taste modification is undesirable. Indeed, mucilage coating exalted some important parameters, such as firmness, brightness, aroma, sweetness, and taste that are particularly appreciated by consumers.

The application of $O$. ficus-indica mucilage was not able to reduce microbial growth below the detection limits, but its application consistently limited their development during refrigerated storage, proving to be effective in prolonging cactus pear fruits shelf life.

In conclusion, our data suggest that $O$. ficus-indica mucilage could be a useful environmentally friendly way of maintaining minimally processed cactus pear fruits quality, nutraceutical value, visual quality, sensorial traits, and extending its postharvest life.

Author Contributions: Conceptualization, G.L.; methodology, G.L., C.G. and R.G.; validation, G.L., R.G., C.G., P.I. and L.S.; formal analysis, G.L., G.G., R.G., C.G.; investigation, G.L., G.G.; resources, G.L., L.S. and C.G.; data curation, G.L., R.G., C.G.; writing-original draft preparation, G.L., C.G., R.G., L.S., P.I.; writing—review and editing, G.L., C.G., R.G., L.S., P.I.; visualization, G.L., C.G., G.G., R.G., L.S., P.I.; supervision, G.L. All authors have read and agreed to the published version of the manuscript.

Funding: This research received no external funding.

Acknowledgments: We thank the "Garufa" cactus pear farm for granting access to the farm facilities and to give us the fruits without undue reservations.

Conflicts of Interest: The authors declare no conflict of interest.

\section{References}

1. Liguori, G.; Inglese, P. Cactus pear (o. Ficus-indica (1.) Mill.) Fruit production: Ecophysiology, orchard and fresh-cut fruit management. Acta Hortic. 2015, 1067, 247-252. [CrossRef]

2. Piga, A. Cactus pear: A fruit of nutraceutical and functional importance. J. Prof. Assoc. Cactus. Develop. 2004, 6, 9-22.

3. Gentile, C.; Tesoriere, L.; Allegra, M.; Livrea, M.; D'Alessio, P. Antioxidant Betalains from Cactus Pear (Opuntia ficus-indica) Inhibit Endothelial ICAM-1 Expression. Ann. New York Acad. Sci. 2004, 1028, 481-486. [CrossRef] [PubMed]

4. Cefola, M.; Renna, M.; Pace, B. Marketability of ready-to-eat cactus pear as affected by temperature and modified atmosphere. J. Food Sci. Technol. 2014, 51, 25-33. [CrossRef]

5. Palma, A.; Continella, A.; La Malfa, S.; D'Aquino, S. Changes in physiological and some nutritional, nutraceuticals, chemicalphysical, microbiological and sensory quality of minimally processed cactus pears cvs 'Bianca', 'Gialla' and 'Rossa' stored under passive modified atmosphere. J. Sci. Food Agric. 2018, 98, 1839-1849. [CrossRef] [PubMed]

6. Piga, A.; D'Aquino, S.; Agabbio, M.; Emonti, G.; Farris, G. Influence of Storage Temperature on Shelf-life of Minimally Processed Cactus Pear Fruits. LWT 2000, 33, 15-20. [CrossRef]

7. Liguori, G.; Gaglio, R.; Settanni, L.; Inglese, P.; D'Anna, F.; Miceli, A. Effect of Opuntia ficus-indica Mucilage Edible Coating in Combination with Ascorbic Acid, on Strawberry Fruit Quality during Cold Storage. J. Food Qual. 2021, 2021, 1-8. [CrossRef]

8. Pushpendra, K.; Shruti, S. Edible coating for fresh fruit: A review. Int. J. Current Microbiol. Appl. Sci. 2018, 7, $2619-2626$.

9. Tapia, M.; Rojas-Graü, M.; Carmona, A.; Rodríguez, F.; Soliva-Fortuny, R.; Martin-Belloso, O. Use of alginate- and gellan-based coatings for improving barrier, texture and nutritional properties of fresh-cut papaya. Food Hydrocoll. 2008, 22, $1493-1503$. [CrossRef]

10. Allegra, A.; Inglese, P.; Sortino, G.; Settanni, L.; Todaro, A.; Liguori, G. The influence of Opuntia ficus-indica mucilage edible coating on the quality of 'Hayward' kiwifruit slices. Postharvest Biol. Technol. 2016, 120, 45-51. [CrossRef]

11. Sogvar, O.B.; Saba, M.K.; Emamifar, A. Aloe vera and ascorbic acid coatings maintain postharvest quality and re-duce microbial load of strawberry fruit. Postharv. Biol. Technol. 2016, 114, 29-35. [CrossRef]

12. Del Nobile, M.; Conte, A.; Scrocco, C.; Brescia, I. New strategies for minimally processed cactus pear packaging. Innov. Food Sci. Emerg. Technol. 2009, 10, 356-362. [CrossRef]

13. Allegra, A.; Sortino, G.; Inglese, P.; Settanni, L.; Todaro, A.; Gallotta, A. The effectiveness of Opuntia ficus-indica mucilage edible coating on post-harvest maintenance of 'Dottato' fig ( Ficus carica L.) fruit. Food Packag. Shelf Life 2017, 12, 135-141. [CrossRef]

14. Del-Valle, V.; Hernández-Muñoz, P.; Guarda, A.; Galotto, M. Development of a cactus-mucilage edible coating (Opuntia ficus indica) and its application to extend strawberry (Fragaria ananassa) shelf-life. Food Chem. 2005, 91, 751-756. [CrossRef]

15. Aquino, L.V.; Rodriguez, J.; Mendez, L.L.; Torres, K.F. Inhibicion del oscurecimiento con mucilago de nopal (Opuntia ficus-indica) en el secado se platano roatan. Informacion Tecnol. 2009, 20, 15-20. [CrossRef]

16. Riaz, S.; Sultan, M.T.; Sibt-E-Abass, M.; Imran, M.; Ahmad, R.S.; Hussain, M.B.; Shariati, M.A.; Kosenko, I.; Kleymenova, N.L.; Egorova, G.N. Extraction of Polysaccharides From Opuntia Cactus For Its Potential Application In Edible Coating to Improve The Shelf Life of Citrus (Kinnow Mandarin) Fruit. J. Microbiol. Biotechnol. Food Sci. 2018, 8, 745-750. [CrossRef]

17. Sáenz, C.; Sepúlveda, E.; Matsuhiro, B. Opuntia spp mucilage's: A functional component with industrial perspectives. J. Arid. Environ. 2004, 57, 275-290. [CrossRef] 
18. Du Toit, A.; De Wit, M. A Process for Extracting Mucilage from Opuntia Ficus-Indica and Aloe Barbadensis. South Africa Patent No. PA153178/P, 12 May 2011.

19. McGuire, R.G. Reporting of Objective Color Measurements. HortScience 1992, 27, 1254-1255. [CrossRef]

20. Mannino, G.; Perrone, A.; Campobenedetto, C.; Schittone, A.; Bertea, C.M.; Gentile, C. Phytochemical profile and antioxidative properties of Plinia trunciflora fruits: A new source of nutraceuticals. Food Chem. 2020, 307, 125515. [CrossRef]

21. Kanner, J.; Harel, S.; Granit, R. BetalainsA New Class of Dietary Cationized Antioxidants. J. Agric. Food Chem. 2001, 49, 5178-5185. [CrossRef]

22. Schwartz, S.J.; von Elbe, J.H. Quantitative determination of individual betacyanin pigments by high-performance liquid chromatography. J. Agric. Food Chem. 1980, 28, 540-543. [CrossRef]

23. Butera, D.; Tesoriere, L.; DI Gaudio, F.; Bongiorno, A.; Allegra, M.; Pintaudi, A.M.; Kohen, R.; Livrea, M.A. Antioxidant Activities of Sicilian Prickly Pear (Opuntia ficus indica) Fruit Extracts and Reducing Properties of Its Betalains: Betanin and Indicaxanthin. J. Agric. Food Chem. 2002, 50, 6895-6901. [CrossRef]

24. Piattelli, M.; Minale, L.; Prota, G. Isolation, structure and absolute configuration of indicaxanthin. Tetrahedron 1964, 20, $2325-2329$. [CrossRef]

25. Ozgen, M.; Reese, R.N.; Tulio, A.Z.; Scheerens, J.C.; Miller, A.R. Modified 2, 2-azino-bis-3-ethylbenzothiazoline-6-sulfonic acid (ABTS) method to measure anti- oxidant capacity of selected small fruits and comparison to ferric reducing anti- oxidant power (FRAP) and 2,2'-diphenyl-1-picrylhydrazyl (DPPH) methods. J. Agric. Food Chem. 2006, 54, 1151-1157. [CrossRef] [PubMed]

26. Ranganna, S. Manual of Analysis of Fruit and Vegetable Products; McGraw-Hill Publishing Co. Ltd.: New Delhi, India, 1977.

27. Amodio, M.L.; Cabezas-Serrano, A.B.; Rinaldi, R.; Colelli, G. Implementation of rating scales for visual quality evaluation of various vegetable crops. In Produce Quality Rating Scales and Color Charts Postharvest Horticulture; Series No. 23; Kader, A.A., Cantwell, M., Eds.; University of California: Davis, CA, USA, 2007.

28. Andreu-Coll, L.; García-Pastor, M.; Valero, D.; Amorós, A.; Almansa, M.S.; Legua, P.; Hernández, F. Influence of Storage on Physiological Properties, Chemical Composition, and Bioactive Compounds on Cactus Pear Fruit (Opuntia ficus-indica (L.) Mill.). Agriculture 2021, 11, 62. [CrossRef]

29. Jain, V.; Chawla, S.; Choudhary, P.; Jain, S. Post-harvest calcium chloride treatments influence fruit firmness, cell wall components and cell wall hydrolyzing enzymes of Ber (Ziziphus mauritiana Lamk.) fruits during storage. J. Food Sci. Technol. 2019, 56, 4535-4542. [CrossRef]

30. García, J.; Herrera, S.; Morilla, A. Effects of Postharvest Dips in Calcium Chloride on Strawberry. J. Agric. Food Chem. 1996, 44, 30-33. [CrossRef]

31. Irfan, P.; Vanjakshi, V.; Prakash, M.K.; Ravi, R.; Kudachikar, V. Calcium chloride extends the keeping quality of fig fruit (Ficus carica L.) during storage and shelf-life. Postharvest Biol. Technol. 2013, 82, 70-75. [CrossRef]

32. Singh Bhooriya, M.; Bisen, B.P.; Pandey, S.K. Effect of post-harvest treatments on shelf life and quality of Guava (Psidiun guavajava) fruits. Int. J. Chem. Stud. 2018, 6, 2559-2564.

33. Manganaris, G.; Vasilakakis, M.; Diamantidis, G.; Mignani, I. The effect of postharvest calcium application on tissue calcium concentration, quality attributes, incidence of flesh browning and cell wall physicochemical aspects of peach fruits. Food Chem. 2007, 100, 1385-1392. [CrossRef]

34. Gheribi, R.; Khwaldia, K. Cactus Mucilage for Food Packaging Applications. Coatings 2019, 9, 655. [CrossRef]

35. Ochoa-Velasco, C.E.; Guerrero-Beltrán, J. Ángel Postharvest quality of peeled prickly pear fruit treated with acetic acid and chitosan. Postharvest Biol. Technol. 2014, 92, 139-145. [CrossRef]

36. Allegra, A.; Sortino, G.; Miciletta, G.; Riotto, M.; Fasciana, T.; Inglese, P. The influence of harvest period and fruit ripeness at harvest on minimally processed cactus pears (Opuntia ficus-indica L. Mill.) stored under passive atmosphere. Postharvest Biol. Technol. 2015, 104, 57-62. [CrossRef]

37. Herbach, K.M.; Stintzing, F.C.; Carle, R. Betalain Stability and Degradation?Structural and Chromatic Aspects. J. Food Sci. 2006, 71, R41-R50. [CrossRef]

38. Howard, L.; Hernandez-Brenes, C. Antioxidant content and market quality of jalapeno pepper rings as affected by minimal processing and modified atmosphere packaging. J. Food Qual. 1998, 21, 317-327. [CrossRef]

39. El-Samahy, S.; El-Hady, A.; Habiba, R.; Moussa, T. Chemical and rheological characteristics of orange-yellow cactus-pear pulp from Egypt. J. Prof. Assoc. Cactus. 2006, 8, 39-51.

40. Felker, P.; Rodriguez, S.D.C.; Casoliba, R.; Filippini, R.; Medina, D.; Zapata, R. Comparison of Opuntia ficus indica varieties of Mexican and Argentine origin for fruit yield and quality in Argentina. J. Arid. Environ. 2005, 60, 405-422. [CrossRef]

41. Saenz, C. Processing technologies: An alternative for cactus pear (Opuntia spp.) fruits and cladodes. J. Arid. Environ. 2000, 46, 209-225. [CrossRef]

42. Brackett, R. Microbiological consequences of minimally processed fruits and vegetables. J. Food Qual. 1987, 10, 195-206. [CrossRef]

43. Potter, A.; Murray, J.; Lawson, B.; Graham, S. Trends in product recalls within the agri-food industry: Empirical evidence from the USA, UK and the Republic of Ireland. Trends Food Sci. Technol. 2012, 28, 77-86. [CrossRef]

44. Miceli, A.; Settanni, L. Influence of agronomic practices and pre-harvest conditions on the attachment and development of Listeria monocytogenes in vegetables. Ann. Microbiol. 2019, 69, 185-199. [CrossRef]

45. Choi, M.H.; Park, Y.J.; Kim, M.; Seo, Y.H.; Kim, Y.A.; Choi, J.Y.; Yong, D.; Jeong, S.H.; Lee, K. Increasing Incidence of Listeriosis and Infection-associated Clinical Outcomes. Ann. Lab. Med. 2018, 38, 102-109. [CrossRef] [PubMed] 
46. Jacxsens, L.; Devlieghere, F.; Debevere, J. Behaviour of Listeria monocytogenes and Aeromonas spp. on fresh-cut produce packaged under equilibrium modified atmosphere. J. Food Prot. 1999, 62, 1128-1135. [CrossRef] [PubMed]

47. Jay, J.M.; Loessner, M.J.; Golden, D.A. Microbiologia Degli Alimenti; Springer Science and Business Media LLC: Mailand, Italy, 2009. 